\title{
BAB V
}

\section{PENUTUP}

\subsection{KESIMPULAN}

Matriks lembut kabur merupakan matriks yang direpresentasikan dari himpunan lembut kabur dan himpunan kabur. Dari definisi matriks lembut kabur ini, dapat diperoleh beberapa sifat-sifat aljabarnya yang terkait dengan irisan, gabungan dan komplemen dari matriks-matriks lembut kabur tersebut.

Pada tesis ini juga diberikan contoh aplikasi matriks lembut kabur dalam pengambilan keputusan. Contoh aplikasinya adalah pengambilan keputusan dalam penentuan pemilihan rumah dan pemilihan mobil pada perusahaan asuransi yang memiliki potensi terbesar berdasarkan pertimbangan beberapa faktor pemilihan yang sama. Penerapan matriks lembut kabur ini pada beberapa aplikasi dalam

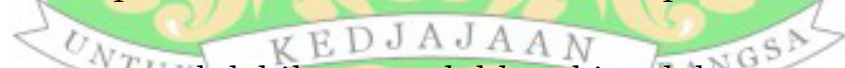

kehidupan berguna untuk lebih memudahkan kita dalam pengambilan keputusan.

\subsection{SARAN}

Pada tesis ini matriks lembut kabur diaplikasikan pada satu kasus saja. Penulis berharap selanjutnya matriks lembut kabur ini dapat diaplikasikan pada berbagai kasus lain dalam kehidupan. 